\title{
Faktor- Faktor Pengambilan Keputusan Klinis Perawat di Ruang IGD
}

\author{
Yohana Pasaribu \\ yohanapasaribu2@gmail.com
}

\section{Latar Belakang}

Instalasi Gawat Darurat (IGD) umumnya memberikan pelayanan perawatan pada pasien selama 24 jam setiap harinya. Jumlah kunjungan pasien ke IGD pada beberapa tahun terakhir mengalami peningkatan. Pada tahun 1994 terdapat 93 juta kunjungan dan pada tahun 2005 sebanyak 115 juta kunjungan (Tsai, C, 2009). Kunjungan pasien ini semakin meningkat tajam pada tahun 2011 dengan jumlah pasien lebih dari 131 juta (Weiss, et al, 2014). Peningkatan jumlah kunjungan ini dapat mengakibatkan pelayanan di IGD menjadi overcrowded (Van Gerven, et al. 2001, Roukema, et al. 2006, Van der Wulp, et al. 2008) dan mengganggu kualitas pelayanan (National Center for Health Statistics (U.S), 2004). Jumlah pasien yang tidak bisa diprediksi ini datang ke IGD dengan berbagai macam kondisi yang meliputi kondisi mengancam nyawa, urgensi maupun cedera atau sakit ringan. Proses pengambilan keputusan klinis merupakan komponen penting dalam proses keperawatan (Diana Catarina, 2009), sehingga dibutuhkan kemampuan perawatan karena Keterbatasan pengetahuan dan kemampuan yang dimiliki perawat dapat menghambat perawat dalam mengambil keputusan mengenai perawatan yang akan diberikan kepada klien yang akan berakibat fatal terhadap klien (Kozier et al, 2010).

Penilaian dan keputusan klinis sangat dibutuhkan untuk mendapatkan kualitas pelayanan yang optimal. Pemberian asuhan keperawatan harus berdasarkan nilai-nilai dan etika yang dianut oleh klien dan nilai-nilai profesional asuhan keperawatan. Mengkombinasikan nilai profesional, etik dan nilai yang di anut klien akan meningkatkan pelayanan, identifikasi kebutuhan dan masalah keperawatan lebih sistematis sehingga meningkatkan pemahaman klien dalam pengambilan keputusan asuhannya (Doheni. 1992, Potter. 2005, Jan florin. 2007). Keputusan klinis adalah suatu proses yang meliputi diagnosis klinis, penilaian dan keputusan tentang apa yang harus dilakukan (Ennis 1996). Proses pengambilan keputusan dalam praktik klinik keperawatan dipahami sebagai serangkaian keputusan yang dibuat oleh perawat dalam interaksinya dengan pasien mengenai jenis pengamatan yang akan dilakukan dalam situasi yang di alami klien (pengkajian keperawatan), perumusan diagnosa keperawatan, rencana tindakan keperawatan yang harus diambil, tindakan keperawatan yang akan diambil serta evaluasi (Dianan 
Catarina. 2009, Jan Florin. 2007, Mehee, 2014). Perlu difahami bahwa istilah keputusan klinis merupakan pilihan dianatara alternatif yang ada sebagai upaya pemecahan masalah (Dowei, 1993).

Kata Kunci : Faktor-faktor, Pengambilan, Keputusan, Klinis, Perawat, UGD

\section{METODE}

Jurnal ini menggunakan metode literature review dari berbagai sumber seperti buku referensi jurnal dan juga membandingkan beberapa jurnal yang berhubungan dengan FaktorFaktor Pengambilan Keputusan Klinis Perawat di Ruang IGD .Dari analisi berbagai sumber yang digunakan untuk mengetahui Faktor-Faktor Pengambilan Keputusan Klinis Perawat di Ruang IGD. Pengolahan jurnal dilakukan dengan metode membandingkan beberapa jurnal yang berkaitan dengan Faktor-Faktor Pengambilan Keputusan Klinis Perawat di Ruang IGD.

\section{HASIL}

Berdasarkan analisa dan eksplorasi serta kajian jurnal ebook .Penulis dapat mengetahui bahwa Secara konsep, perawat merupakan petugas kesehatan yang mempunyai peran dan tanggung jawab utama dalam melakukan triage di Instalasi Gawat Darurat (IGD) (Andersson, Omberg \& Svedlund, 2006). Di Ruang Instalasi Gawat Darurat terdapat tuntutan akan pemenuhan kebutuhan akses kegawatdaruratan, dalam hal ini kekurangan sumber daya terhadap kebutuhan dapat meningkatkan kepadatan dan hambatan akses yang mengakibatkan peningkatan waktu tunggu pasien untuk menempati tempat perawatan. Sebuah usaha harus dilakukan untuk meningkatkan ketersediaan tempat perawatan dan pengembangan program. Unit Gawat Darurat harus melaksanakan pengembangan secara berkelanjutan untuk pemenuhan efisiensi operasional (College Emegency Nursing Australia, 2007).

Triase adalah aspek penting dalam merawat pasien di ruang IGD berupa penilaian awal yang dilakukan selama pasien masuk ke IGD. Triase adalah langkah yang paling penting dalam ruangan gawat darurat. Tujuan utama dari triase adalah untuk menurunkan angka kesakitan dan kematian bagi seluruh pasien yang masuk ke IGD (Garbez et al., 2011). Sistem triase dikenalkan oleh Hanysides sebagai tujuan untuk untuk memprioritaskan tingkat urgensi diantara pasien yang datang ke IGD.

Kesalahan pengambilan keputusan, apalagi dalam pengkategorian pasien dengan kategori poor triage menyebabkan keterlambatan pengobatan dan ketidakmampuan serta cacat permanen bagi pasien.Tanggung jawab tersebut menuntut perawat untuk terus mengembangkan perannya 
dalam hal mengambil keputusan yang tepat terutama dalam penentuan prioritas kegawatdaruratan pada instalasi gawat darurat. Dalam pengambilan keputusan terdapat faktorfaktor yang mempengaruhi perawat dalam melaksanakan triage antara lain faktor internal mencakup kemampuan psikomotor dan kapasitas personal perawat, sedangkan faktor eksternal adalah lingkungan kerja di IGD yang cenderung overcrowded (Gerdtz And Bucknall, 2001).

Pada kegiatan triage perawat bertanggung jawab untuk dapat mengambil keputusan segera (decision making), melakukan pengkajian resiko, pengkajian sosial, diagnosis, menentukan prioritas dan merencanakan tindakan berdasarkan tingkat urgency pasien (Sands, 2007). Perawat juga bertanggung jawab memberi dukungan kepada pasien dan keluarga selama di ruang emergency, membangun komunikasi yang baik antara tenaga kesehatan dengan pasien atau keluarga serta memberi saran, edukasi dan konsultasi dalam membuat perencanaan tindakan bersama (Sands, 2004).

Sepanjang komponen dari proses keperawatan, perawat menggunakan sikap dan kemampuan berfikir kritis untuk menentukan relevansi, makna dan iterrelasi data pasien serta untuk memilih dan menetapkan asuhan keperawatan yang sesuai (Cristensen \& Kenney, 2009). Berfikir kritis penting dilakukan sebelum mengambil keputusan dalam asuhan keperawatan karena merupakan salah satu metode ilmiah dalam menyelesaikan masalah klien. Kemampuan perawat mengidentifikasi masalah klien dan memilih solusi intervensi yang tepat tidak lepas dari kemampuan perawat berfikir kritis untuk mengali berbagai alasan berdasarkan evidence base dari setiap problem dan solusi yang teridentifikasi (Potter\& Perry, 2010).

Dari beberapa uraian diatas faktor-faktor yang berperan dalam pengambilan Keputusan Klinis Perawat di Ruang IGD.

\section{PEMBAHASAN}

\section{PENGAMBILAN KEPUTUSAN KLINIS KEPERAWATAN}

Beberapa konsep yang digunakan untuk menggambarkan berpikir kritis dalam keperawatan adalah penalaran klinis, perumusan diagnostik, pengambilan keputusan, penilaian, dan pemecahan maslah. Menurut penelitian yang dilakukan oleh Panggabean, 2019 kemampuan berfikir kritis perawat dalam pengambilan keputusan klinis berhubungan erak dengan kemampuan berfikir kritis perawat dengan nilai $p=0,026$ dan juga menurut Khairina, 2018 pengalaman kerja mempunyai hubungan erat dengan kemampuan pengambilan keputusan klinis dengan nilai $\mathrm{p}$ value 0,012 . 
Berpikir kritis digambarkan sebagai "sebuah proses, tujuan untuk membuat keputusan yang masuk akal tentang apa yang harus percaya dan apa yang harus dilakukan". Pengambilan keputusan klinis adalah sebuah proses yang melibatkan kedua penalaran diagnostik dan penilaian klinis. Tindakan dalam ini tindakan diarahkan sebagai proses refleksi dari perawat maupun pasien (Jan Florin, 2007). Pengambilan keputusan sangat penting keberadaannya dalam asuhan maupun dalam manajemen keperawatan. Pengambilan keputusan merupakan suatu proses yang mencakup semua penilaian kegiatan yang diperlukan guna membuktikan dan meperlihatkan pilihan terbaik dalam menyelesaiakan suatu masalah tertentu. setiap keputusan adalah akibat dari sebuah proses dinamis yang dipengaruhi oleh banyak kekuatan, pengambilan keputusana bukan merupakan prosedur yang tetap akan tetapi sebuah proses yang beruntun. pengambilan keputusan adalah proses yang melibatkan pendekatan sistemik yang harus diadaptasikan dengan lingkungan. Bagaimanan perawat dalam mengambil keputusan klinis? Pengambilan keputusan keperawatan dilakukan pada semua tahap proses keperawatan. Sehingga seorang perawat harus mampu berpikir ktitis, berkomunikasi dengan baik sebagai suatu elemen penting dalam pengaambilan keputusan klinis, sehingga terjadi pembelajaran berkelanjutan bagi pasien sehingga meningkatkan tingkat kemandirian pasien.

Definisi lain dijelaskan bahwa pengambilan keputusan klinis keperawatan merupakan serangkaian keputusan yang dibuat oleh perawat, dalam interaksi dengan klien mengenai pengkajian yang didapat dari klien, evaluasi data yang diamati, variasi diagnosa yang muncul serta tindakan keperawatan yang harus diambil (jan Florin. 2007, Mehee. 2014). Teori yang dikemukakan oleh Buckingham and Adams pengambilan keputusan klinis merupakan perilaku klasifikasi (Jan Florin. 2007). Klasifikasi dapat diartikan bahwa pengambilan keputusan merupakan sebuah pola tertentu sama halnya dengan proses keperawatan, jelas bahwa dalam setiap proses keperawatan perawat harus mampu mengambil keputusan klinis. Sedangkan menurut Guyatt (Agung pranoto. 2013) menjelaskan bahwa asuhan yang berdasarkan evidence base pengambilan keputusan harus melibatkan pasien. Sehingga penting bagi perawat untuk mampu mengambil keputusan dengan baik, cepat dan akurat dalam hal ini menurut Sumijatun (Samijatun 2009) perlu dipahami bagi perawat bahwa pengambilan keputusan klinis dengan melibatkan klien akan erat hubungannya dengan nilai-nilai budaya yang dianut oleh klien.

\section{JENIS KEPUTUSAN DI INSTALASI GAWAT DAURAT (IGD)}


Proses asuhan keperawatan umumnya tidak berubah di setiap kelompok karena memang demikian standar; namun, pilihan yang paling sering dibuat di IGD mungkin berbeda dengan unit lain, dengan mempertimbangkan sifat spesifik pasien dan lingkungan Hidup. Sebuah studi terbaru (13) menyarankan ada tiga jenis keputusan klinis kegiatan yang dilakukan oleh perawat perawatan kritis: intervensi, komunikasi, dan evaluasi. Ketiga kategori aktivitas keputusan klinis ini akan mendorong perawat untuk melakukannya merumuskan keputusan baru atau mempertahankan keputusan yang ada

\section{a) Keputusan intervensi}

Di IGD pasien umumnya adalah pasien yang dirawat total; Oleh karena itu intervensi keputusan mungkin salah satu keputusan paling umum yang dibuat oleh perawat. Bucknall (13) menemukan keputusan intervensi yang dibuat oleh perawat perawatan kritis yang terlibat masalah tersebut seperti pemosisian, penyedotan, dan beberapa aspek lain dari perawatan pasien langsung. Perawat bisa putuskan intervensi baru ketika mereka memulai terapi baru atau memodifikasi pasien yang sudah ada peduli, atau mereka mungkin melanjutkan dengan intervensi 'lama'. Keputusan intervensi adalah kegiatan keperawatan untuk memodifikasi pasien (14) .

\section{b) Keputusan komunikasi}

Komunikasi adalah salah satu komponen sentral dalam unit perawatan kritis: penting perawat perawatan berkomunikasi dengan rekan kerja, profesional kesehatan lainnya, pasien dan keluarga mereka. Bucknall (13) menjelaskan bahwa berbagai jenis komunikasi terbukti dalam IGD, yang melibatkan penyelidikan kondisi pasien oleh tim perawatan kesehatan, menawarkan dukungan, dan menyampaikan informasi tentang kondisi terkini pasien tersebut kepada staf lain dan anggota keluarga. Bucknall (13) mengemukakan bahwa perawat melakukan komunikasi baru keputusan jika mereka memulai komunikasi dengan anggota tim lain atau anggota keluarga, sementara hanya keputusan komunikasi lama yang akan terjadi jika mereka menindaklanjuti yang ada keputusan komunikasi.

\section{c) Keputusan evaluasi}


Evaluasi adalah jenis penilaian lain, yang tampaknya sering dilakukan IGD, sementara secara dominan merawat pasien yang tidak sadar. Seperti yang ditegaskan Bucknall (13), perawat perawatan kritis terus mengamati status pasien, mengkategorikan data berdasarkan itu relevansi dan pentingnya; mereka memvalidasi dan mengatur data, mengidentifikasi pola dan korelasi, membuat kesimpulan, merumuskan hipotesis dan mengevaluasinya. Demikian pula dengan Benner (15), salah satu peran utama perawat adalah menilai perubahan pasien, dan memang begitu diikuti dengan mengelola perubahan.

\section{3. faktor yang mempengaruhi pengambilan keputusan di IGD}

Ada berbagai aspek yang diyakini menjadi faktor pengontrol untuk penilaian dan keputusan klinis. Beberapa penelitian menyelidiki faktor-faktor tersebut, yaitu: perawat pengalaman, kondisi pasien, sumber daya personel, kerja shift, tata letak IGD, teknologi di IGD, kolaborasi antar-profesional, akuntabilitas, dan otoritas

\section{a) Pengalaman perawat}

Di sebagian besar pengaturan klinis, pengalaman keperawatan tampaknya berpengaruh signifikan faktor dalam proses pengambilan keputusan, dan ini tampaknya benar di ICU. Bucknall melakukan penelitian dengan menggunakan desain natural yang menemukan bahwa pengalaman perawat mempengaruhi proses pengambilan keputusan mereka. Peneliti menunjukkan bahwa perawat dengan pengalaman lebih dari lima tahun cenderung mengkomunikasikan keputusan mereka kepada orang lain. Mungkin karena perawat yang berpengalaman lebih cenderung ditempatkan pada pasien dengan kondisi yang lebih rumit dibandingkan perawat yang kurang berpengalaman, dan berpengalaman perawat umumnya bertanggung jawab untuk mendampingi perawat yang kurang berpengalaman. Jadi, perawat berpengalaman dituntut untuk lebih sering berkomunikasi melalui pengaturan pilihan pengobatan, memeriksa kemajuan pasien, dan mengajarkan pilihan untuk manajemen pasien. Sebaliknya, perawat dengan pengalaman kurang dari lima tahun cenderung melakukannya membuat keputusan evaluatif. Hasil ini mungkin disebabkan oleh kesulitan mereka dalam mengidentifikasi apakah data itu penting dan relevan, atau tidak penting atau tidak relevan, jadi mereka terus fokus untuk menemukan tren di monitor pasien. 
Pengalaman perawat diyakini sebagai faktor paling berpengaruh dalam pengambilan keputusan proses pembuatan, terutama saat menggunakan intuisi. Bjørk dkk. berpendapat bahwa pendidikan, jenis kelamin, usia, dan bidang praktik mungkin memengaruhi penggunaan CDM interpretatif-intuitif; Namun, faktor utama yang mempengaruhi adalah pengalaman. Perawat yang kurang berpengalaman berbeda dari perawat berpengalaman dalam hal kemampuan menganalisis data dan membuat keputusan .

Membahas pengalaman merupakan faktor yang berpengaruh, penting bagi manajer perawat untuk mempertimbangkan faktor ini saat mengatur shift keperawatan. Bucknall membantahnya sangat penting untuk membuat kombinasi personel yang layak di setiap shift, berdasarkan mereka pengalaman; sehingga pengambilan keputusan klinis yang efektif dapat dipertahankan setiap saat, 24 jam sehari. Bucknall juga menunjukkan bahwa perawat yang berpengalaman mungkin menganggapnya a tantangan untuk menyampaikan informasi yang memadai dan berbagi pendapat, untuk mendukung pemula di memutuskan apakah mereka bertanggung jawab atas terlalu banyak siswa pada saat itu.

\section{b) Pengetahuan perawat}

Pengetahuan perawat dapat berkontribusi pada pengambilan keputusan di ICU. Perawat pengetahuan dapat mempengaruhi kinerja mereka dalam pengambilan keputusan . Aitken dkk. (7)

Menunjukkan beberapa faktor seperti pengetahuan, sikap, dan keyakinan tentang sedasi, pengalaman sebelumnya, dan keterampilan penilaian klinis semua bisa mempengaruhi penilaian perawat dan pengambilan keputusan. Mereka berpendapat bahwa pengetahuan perawat tentang berbagai macam isi dan atribut yang berkaitan dengan masalah seperti penilaian, fisiologi, dan pengobatan mempengaruhi kemampuan mereka dalam penilaian klinis dan pengambilan keputusan dalam obat penenang pengelolaan. Mereka lebih lanjut menegaskan bahwa perawat tidak terlalu memperhitungkan faktor fisiologis sebelum membuat keputusan klinis; 'titik buta' ini mungkin menunjukkan kurangnya pemahaman fisiologi, atau mungkin mencerminkan bahwa sebelum membuat keputusan intervensi, para ahli melakukannya tidak perlu pertimbangan sadar terkait fisiologi.

\section{c) Kondisi pasien}


Kompleksitas situasi pasien dapat mempengaruhi jenis keputusan dan keputusan telah dibuat. Seperti yang ditegaskan Bucknall, pengambilan keputusan klinis perawat adalah umumnya dipengaruhi oleh status kesehatan pasien. Komplikasi kondisi pasien mempengaruhi kecepatan, bentuk, dan kerumitan keputusan. Dia berpendapat bahwa perawat mungkin mengalami rasa kurang percaya diri saat merawat pasien dengan presentasi langka situasi; persepsi diri, yang dapat mempengaruhi kecepatan pengambilan keputusan proses. Lebih lanjut, dia juga menunjukkan bahwa perawat bisa mendapatkan kepercayaan diri memutuskan apakah mereka memiliki kesempatan untuk mendiskusikan kasus mereka dengan lebih banyak orang perawat berpengalaman. Bucknall menyatakan bahwa situasi pasien dapat mempengaruhi jenis keputusan perawat; bisa jadi keputusan intervensi, keputusan komunikasi, evaluasi keputusan, atau kombinasi dari semua ini.

Aitken dkk. menyatakan bahwa faktor yang berkontribusi dalam pengambilan keputusan untuk obat penenang Penatalaksanaan di IGD meliputi riwayat kesehatan, status kesehatan saat ini, kecemasan, sedasi tingkat, respons pasien terhadap terapi, pengaruh keluarga, dan hasil sedasi manajemen untuk setiap pasien. Mereka juga menunjukkan penilaian sedasi dan penatalaksanaan sangat ditentukan oleh status neurologis pasien; yang lebih berpengaruh dalam penilaian dan manajemen sedasi daripada nyeri dan kenyamanan. Ini mungkin karena data yang dikumpulkan dari penilaian status neurologis ternyata lebih banyak obyektif daripada hasil evaluasi status kenyamanan. Namun, tujuannya adalah nyeri penilaian ditingkatkan dengan menggunakan alat pengukuran seperti skala peringkat numeric (NRS), atau skala nyeri perilaku (BPS). Studi menemukan efek positif dari penerapan perangkat di bidang penilaian klinis dan pengambilan keputusan. Dengan menggunakan latar belakang pengetahuan dan pengalaman perawat mungkin dapat mentranskripsikan hasil alat penilaian untuk membuat penilaian klinis yang kuat.

\section{d) Tata letak instalasi gawat darurat}

Desain instalasi gawat darurat dapat mempengaruhi pembuatan keputusan klinis perawat. Bucknall menilai bahwa perawat yang bekerja di dengan tata letak ruangan tertutup cenderung kurang berkomunikasi dengan anggota tim lainnya, dibandingkan dengan perawat yang bekerja dalam desain terbuka. Dia berpendapat bahwa rencana akhir mungkin meningkatkan kemandirian perawat saat memutuskan karena mereka cenderung berkomunikasi 
anggota tim lain hanya jika diperlukan. Perawat yang bekerja di tata letak akhir cenderung melakukannya membuat lebih sedikit keputusan komunikasi daripada jenis keputusan lainnya . Selanjutnya, Bucknall menunjukkan bahwa unit perawatan kritis rencana terbuka dapat mengakomodasi keduanya pasien dan penyedia layanan kesehatan, sedangkan tata letak yang terbatas dan kurang nyaman mungkin memicu stres perawat dan mungkin bekerja melawan kualitas pengambilan keputusan proses.

\section{e) Shift kerja}

Jenis dan proses keputusan klinis yang dibuat oleh perawat juga dipengaruhi oleh kerja shift. Studi sebelumnya menemukan bahwa keputusan kerja dibuat oleh perawat pada malam hari tugas sebagian besar adalah keputusan tipe evaluasi: ada lebih sedikit intervensi dan komunikasi selama jam malam, untuk menjaga kualitas tidur pasien. Lain alasan mengapa perawat tidak membuat banyak keputusan komunikasi selama shift malam adalah penurunan partisipasi profesional perawatan kesehatan lainnya selama waktu itu .

\section{f) Kolaborasi interprofesional}

Kolaborasi multidisiplin dapat memengaruhi banyak keputusan klinis perawat cara; sikap perawat terhadap kolaborasi antar-profesional mungkin bergantung pada mereka jaminan untuk berperan dalam tim pembuat keputusan. Bucknall mengemukakan pendapat yang pasti hubungan timbal balik antar multidisiplin merupakan hal mendasar dalam membuat antar- keputusan profesional. Dia berpendapat bahwa perawat dengan pengetahuan yang memadai merasa lebih percaya diri untuk memasuki diskusi dengan profesional kesehatan lainnya; lebih jauh, dokter lebih mengandalkan perawat untuk melanjutkan evaluasi selama jam kerja non-reguler; terutama jika mereka memutuskan untuk menindaklanjuti perawatan berdasarkan informasi perawat.

\section{g) Sumber daya fisik dan personel}

Sumber daya perawat dan peralatan teknologi canggih di IGD dapat memengaruhi proses pengambilan keputusan klinis. Kemampuan perawat dalam menggunakan teknologi canggih mungkin mendukung mereka dalam membuat keputusan klinis yang efektif, menurut Bucknall. Itu juga sering disarankan bahwa sumber daya kepegawaian adalah pengaruh 
signifikan pada membuat; kekurangan perawat dapat meningkatkan beban kerja, dan ini dapat mempengaruhi waktu yang tersedia untuk membuat keputusan .

\section{PENUTUP}

\section{Kesimpulan}

Pengambilan keputusan klinis yang dilakukan oleh perawat di IGD sangat ditentukan oleh beberapa faktor yakni Pengalaman perawat, Pengetahuan perawat, Kondisi Pasien, Tata letak instalasi gawat darurat, Shift kerja, Kolaborasi interprofesional, Sumber daya fisik, dan personel .Untuk meningkatkan pengambilan keputusan klinis perawat di IGD dapat memperbaiki faktor-faktor tersebut.

\section{SARAN}

Untuk para perawat Informasi tentang pengambilan keputusan dan penilaian klinis mungkin dapat menambah wawasan dalam mengambil keputusan klinis yang berkualitas, dan dapat meningkatkan kualitas perawatan.

Untuk Mahasiswa Keperawatan dan perawat pemula dapat mempertimbangkan faktor yang dapat mempengaruhi penilaian klinis dan pengambilan keputusan di IGD.

\section{DAFTAR PUSTAKA}

Ardiyani, M , A. (2019). Analisis Peran Perawat Terhadap Ketepatan Penentuan Prioritas I, II, dan III Pada Ruang Triage di Instalasi Gawat Darurat Rumah Sakit dr Saiful Anwar Malang. JURNAL KEPERAWATAN FLORENCE, 3(2), 15-23.

Deniati, K., Anugrahwati, R., \& Suminarti, T. (2018). Pengaruh Berpikir Kritis Terhadap Kemampuan Perawat Pelaksana Dalam Melakukan Asuhan Keperawatan di Rumah Sakit Hermina Bekasi Tahun 2016. Jurnal Kesehatan Holistik ( The Journal of Holistic Healthcare), 12(1), 21-25.

Faidah, N., Ratnawati, R., \& Setyoadi. (2013). Pengalaman Perawat Dalam Pengambilan Keputusan Triage di Instalasi Gawat Darurat RSUD RAA Soewondo Pati. Jurnal Keperawatan \& Kesehatan Masyarakat, 1(2), 35-43.

Hardisman, H. (2015). Lama rawatan dan mortalitas pasien intensive care unit (ICU) RS Dr.

Djamil Padang Di tinjau dari Beberapa Aspek. Majalah Kedokteran Andalas, 32(2), 142-150. 
Harianto, P, S., Susmarini, D., Haedar, A., \& Widjajanto, E. (2015). Hubungan Pengetahuan Dengan Akurasi Pengambilan Keputusan Perawat Dalam Pelaksanaan Triage. JURNAL ILMIAH KESEHATAN MEDIA HUSADA, 1-7.

Khairina, I., Malini, H, \& Huariani, E. (2018). Faktor-Faktor Yang Berhubungan Dengan Pengambilan Keputusan Perawat Dalam Ketepatan Triase di Kota Padang. Indonesian Journal for Health Sciences, 2(1), 1-6.

Nibbelink, C, W., \& Brewer, B, B. (2018). Decision-Making in Nursing Practice: An Integrative Literature Review. J Clin Nurs, 1-16.

Rahajeng, I, M., \& Muslimah, F. (2019). The Application of Clinical Judgment and Decision Making of Critical Care Nurses in Intensive Care Units (ICUs). International Journal of Nursing and Health Services (IJNHS), 2(1), 1-14.

Rahayu, C, D., \& Mulyani Sri. (2020). Pengambilan Keputusan Klinis Perawat. Jurnal Ilmiah Kesehatan, 1-11.

Simamora, R. H. (2005). Hubungan Persepsi Perawat Pelaksana Terhadap Penerapan Fungsi Pengorganisasian Yang Dilakukan Oleh Kepala Ruangan Dengan Kinerjanya Diruang Rawat Inap RSUD Koja Jakarta Utara (Doctoral dissertation, Tesis FIK UI, Tidak dipublikasikan).

Simamora, R. H. (2019). Menjadi perawat yang: CIH'HUY. Surakarta: Kekata Publisher.

Wøien, H., \& Bjørk, I, T. (2012). Intensive care pain treatment and sedation: Nurses' experiences of the conflict between clinical judgement and standardised care: An explorative study. Intensive \& Critical Care Nursing, 128-136. 